\title{
Use of microbial inoculants for production of potato tuber seed in greenhouse conditions
}

\author{
Uso de inoculantes microbianos para la producción de tubérculos semilla de papa en \\ condiciones de invernadero
}

\section{H. Torres-Vite ${ }^{1}$, S.E. Contreras-Liza ${ }^{1}$}

\begin{abstract}
Objectives: To determine the effect of Glomus intraradices and Bacillus subtilis on the agronomic performance from in vitro potato seedlings in greenhouse conditions. Methodology: The research was developed in pots under greenhouse conditions at Universidad Nacional José Faustino Sánchez Carrión, Huacho, Lima, from October 2017 to March 2018. The substrate for pots was $45 \%$ sand, $45 \%$ vermicompost, and $10 \%$ rice straw, with an average content of $3 \%$ organic matter. The average environmental temperature was $25^{\circ} \mathrm{C}$. In vitro seedlings of five potato genotypes were transplanted into 4-liter pots, and inoculated with commercial inoculants of Glomus intraradices, a mixture of G. intraradices + Bacillus subtilis, a fertilization treatment with NPK (220-180-120) and control without inoculation. Completely randomized design with four replications on a factorial arrangement was used, with four inoculant treatments and five potato genotypes. The data of ten agronomic characters, that included the weight of the tubers and biomass per plant, were subjected to analysis of variance and then to tests of mean comparison of Scott-Knott and processed with Infostat software. Results: Inoculation treatments with mycorrhizae or mycorrhizae with rhizobacteria, statistically surpassed $(P<0.05)$ the controls in the case of weight of tubers per plant, the average weight of tubers, number of tubers per plant and diameter of the tuber, in addition to the height of the plant at 15 and days after the transplant; in the case of fresh foliage weight per plant and the degree of senescence of the foliage, the control treatments statistically surpassed $(P<0.05)$ to the inoculation treatments. For other characters, number of sprouts per plant, the number of leaves and number of flowers per plant, no significant differences $(P>0.05)$ was found. Conclusions: The use of microbial inoculants based on mycorrhizae and rhizobacteria, improves the productivity of potato seed tubers under greenhouse conditions.
\end{abstract}

Keywords: Glomus intraradices, agronomic performance, in vitro seedlings, potato varieties, greenhouse

\section{Resumen}

Objetivos: Determinar el efecto de Glomus intraradices y Bacillus subtilis sobre el comportamiento agronómico de plántulas in vitro de papa, bajo condiciones de invernadero. Metodología: La investigación se desarrolló en macetas bajo condiciones de invernadero en la Universidad Nacional José Faustino Sánchez Carrión, Huacho, Lima, durante octubre del 2017 a marzo del 2018. El sustrato para macetas fue $45 \%$ arena, $45 \%$ vermicompost y $10 \%$ pajilla de arroz, con un contenido medio de $3 \%$ de materia orgánica. La temperatura ambiental promedio fue de $25^{\circ} \mathrm{C}$. Las plántulas in vitro de cinco genotipos de papa fueron trasplantadas a macetas de 4 litros de sustrato e inoculadas con productos comerciales de Glomus intraradices, una mezcla de G. intraradices + Bacillus subtilis, un

\footnotetext{
${ }^{1}$ Universidad Nacional José Faustino Sánchez Carrión, Lima, Perú.

${ }^{2}$ Corresponsal author e-mail: scontreras@unjfsc.edu.pe 
tratamiento con NPK (220-180-120) y un tratamiento sin inoculación, ni fertilización. Se utilizó el diseño completamente al azar (DCA) con cuatro tratamientos y cinco genotipos de papa bajo arreglo factorial. Los datos de diez caracteres agronómicos fueron sometidos a análisis de variancia y luego a pruebas de comparación de medias de Scott-Knott y procesados a través del programa Infostat. Resultados: La inoculación con micorrizas o de micorrizas con rizobacterias, superó estadísticamente $(P<0,05)$ a los controles en el caso de peso de tubérculos por planta, peso medio del tubérculo, número de tubérculos por planta y diámetro del tubérculo, además de la altura de planta a los 15 días del trasplante; en peso fresco del follaje por planta y grado de senescencia del follaje, los tratamientos controles superaron estadísticamente $(P<0,05)$ a los tratamientos de inoculación mencionados. Para los caracteres de número de brotes por planta, número de hojas y número de flores por planta no se presentaron diferencias significativas $(P>0,05)$. Conclusiones: El uso de inoculantes microbianos a base de micorrizas arbusculares y rizobacterias mejora la productividad de tuberculillos de papa en condiciones de invernadero.

Palabras claves: Glomus intraradices, comportamiento agronómico, plántulas in vitro, variedades de papa, invernadero

\section{Introduction}

The last updated statistics of the Peruvian Office of Economic and Statistical Studies of the Ministry of Agriculture and Irrigation (Ministerio de Agricultura y Riego, 2015) indicate that 6211 hectares were cultivated with potatoes during the 2014 agricultural season in the Lima region, with an average yield of 23.7 $\mathrm{tha}^{-1}$. In this potato production system, intensive agricultural technology is used as agricultural inputs (particularly fertilizers, agrochemicals, and crop protection products), mechanization and irrigation. Technical assistance is also provided, but there is a need to evaluate the use of technologies as well as other socioeconomic factors from the viewpoint of environmental, economic and social sustainability.

It is known that microorganisms in agricultural soil exert a profound influence on soil fertility status, in particular availability of nutrients, as well as in the suppression of plant diseases and regulating plant tolerance to stress factors (Yang et al., 2018; Kennedy \& Smith, 1995). There is evidence that soil biodiversity confers stability to stress and disturbance conditions (Brussaard et al., 2007), but the mechanisms are still not fully understood. Oswald et al. (2010) demonstrated in trials under controlled conditions with Bacillus sp., that the mechanisms that cause the best growth of potato plants are among others early tuberization, the rapid development of leaf area, and, probably, a higher rate of photosynthesis. Calvo et al. (2010) conducted a prospection of bacteria extracted from the rhizosphere of native potatoes that grow in their natural habitat in the Andean region and the results suggested that they are a rich source of antagonists for phytopathogenic fungi, mainly the isolates belonging to the genus Bacillus sp. Thus, they concluded that the potato rhizosphere is a source of bacteria to be used in the future as inoculants to improve the agronomic performance of potatoes. Due to the large losses caused by fungal diseases that can damage the potato fields, biocontrol methods using mycorrhizal fungi as protection agents, should be developed in the short term. These microorganisms can compete with taxonomically related phytopathogenic fungi, acting in synergy with growth-promoting bacteria (Diallo et al., 2011).

According to Arcos \& Zúñiga (2015), strains of Bacillus subtilis and B. amyloliquefaciens native to the altiplanic region of Peru and Bolivia, which were inoculated to seedlings of two potato varieties ('Ccompis' and 'Andina'), had the ability to inhibit infection by Rhizoctonia solani in potatoes, possibly through some mechanism of antagonistic action or induced resistance. Oswald et al. (2010) proposed that the use of soil microorganisms could reduce the application of fertilizers in potato cultivation and partially control soil-borne diseases that affect the production and quality of tubers. Velivelli et al. 
(2015) showed that five strains isolated from the rhizosphere in the Andean region (Bolivia, Peru, Ecuador), Pseudomonas palleroniana R43631, Bacillus sp. R47065, R47131, Paenibacillus sp. B3a R49541 and Bacillus simplex M3-4, R49538, significantly increased the yield of potato tubers under field conditions.

According to Naqqash et al. (2016), the strain Azospirillum sp. TN10 produced the highest increase in fresh and dry potato weight regarding control plants, in addition to an increase in $\mathrm{N}$ content in stems and roots. All the strains evaluated in the research were able to colonize and maintain their population densities in the potato rhizosphere for up to 60 days, but Azospirillum sp. and Rhizobium sp. showed the highest relative survival.

On the other hand, Davies et al. (2005) argue that arbuscular mycorrhizal fungi (AMF) are fundamental in potato production systems since they can make plants more efficient in the use of soil water and the availability of nutrients, that is, they serve as biofertilizers and increase resistance to drought and productivity. The authors demonstrated that the use of formonetin (isoflavone) from native $\mathrm{AMF}$ improves the productivity of potato crops in a cost-effective manner. Castillo et al. (2016) state that in a sustainable production system, AMFs together with biofertilizers that include in their composition $\mathrm{N}$-fixing bacteria can be a reliable alternative to partial replacement of chemical fertilizers in potato cultivation.

Duffy \& Cassells (2000) inoculated potato microplants with three commercial mycorrhizal strains and the results confirmed previous findings that $\mathrm{AMF}$ can increase or decrease tuber yield, depending on the mycorrhizal isolate and the host genotype. In this research, the analysis of the foliar images had predictive effects in the evaluation of the potential of the mycorrhizal treatments, in the determination of the yield of the tubers and in the distribution of the size of the potato tuber. Douds et al. (2007) showed that AMF inocula produced in compost and vermiculite can increase the yield of potato tubers under field conditions. Aloo et al. (2019) considers that rhizobacteria-based technology is a viable option for potato bio fertilisation and bioprotection. This could be the missing link in its sustainable cropping.

The main objective of the research was to evaluate potato inoculation with microorganisms Glomus intraradices and Bacillus subtilis, to improve the agronomic performance of potato seed production in the greenhouse.

\section{Methodology}

The greenhouse experiment was carried out during the spring season 2017 in the Universidad Nacional José Faustino Sánchez Carrión greenhouse (Huacho, Lima) at central coast of Peru. Mean air temperatures were $25^{\circ} \mathrm{C}$ (range $23-28^{\circ} \mathrm{C}$ ) while substrate for pots was constituted by $45 \%$ washed sand, $45 \%$ earthworm humus and $10 \%$ rice straw. Organic matter content in the substrate was $3 \%$, according to soil analysis.

In vitro seedlings were provided by the International Potato Center (CIP), recovered in Jiffys-7 and then transplanted into 4-liter pots in the greenhouse, for application of inoculation treatments. For comparative purposes it was used three potato cultivars and two advanced clones from CIP germplasm (table 1) for evaluating four inoculation treatments: Glomus intraradices, Glomus intraradices + Bacillus subtilis, NPK and control (Table 2).

Table 1

Potato genotypes used in the experiment

\begin{tabular}{cccccc}
\hline $\begin{array}{c}\mathrm{N}^{\mathrm{o}} \\
\mathrm{CIP}\end{array}$ & Accesion & Genotypes & Origen & Type & $\begin{array}{c}\text { \# in } \\
\text { vitro } \\
\text { plantlets }\end{array}$ \\
\hline 1 & 392797.2 & Unica & Perú & Cultivar & 20 \\
2 & 380389.1 & Canchan & Perú & Cultivar & 20 \\
3 & 374080.5 & Perricholi & Perú & Cultivar & 20 \\
& & & & & \\
4 & 396311.1 & Yasmine & Advanced & Clone & 20 \\
& & & & & \\
5 & 399101.1 & Faustina & Advanced & Clone & 20 \\
\hline
\end{tabular}


Inoculation with Glomus intraradices was made in the greenhouse substrate, in a dose of $10 \mathrm{~g}$ per plant of commercial formulation for each pot, while Bacillus subtilis inoculation was realized in a water solution (1\%) applied to potato seedlings after planting time and then 45 days after, as described in Table 2.

Table 2

Description of inoculation treatments used in the experiment

\begin{tabular}{|c|c|c|}
\hline $\mathrm{N}^{\mathrm{o}}$ & Inoculation type ${ }^{1}$ & Description \\
\hline 1 & Control & No inoculation \\
\hline 2 & Glomus & $\begin{array}{l}\text { Inoculation at planting with } \\
\text { Glomus intraradices }\end{array}$ \\
\hline 3 & $\begin{array}{l}\text { Glomus }+ \\
\text { Bacillus }\end{array}$ & $\begin{array}{l}\text { Inoculation with Glomus } \\
\text { intraradices and Bacillus } \\
\text { subtilis }\end{array}$ \\
\hline 4 & NPK & Fertilization NPK 220-180-120 \\
\hline
\end{tabular}

The characteristics measured during the experiment for agronomic performance at greenhouse conditions were mean plant height in centimeters (MPH), vegetative uniformity (VUN) and vegetative vigor (VIG) in a scale (1: excellent - 9: very deficient). Also, other traits were measured, number of inflorescences per plant (NFP), number of leaflets per plant (NLP), number of sprouts per plant (NSP) and stem diameter in centimeters (SDI).

At the harvest, the traits evaluated were: tuber weight per plant in grams (TWP), tuber number per plant (TNP), average tuber diameter in centimeters (TDI), mean tuber weight in grams (MTW), dry weight of foliage in grams (DWF), fresh foliage weight in grams (FFW), degree of foliage senescence (DFS) .

Experimental design used was completely randomized design with four replicates in a $5 \times 4$ factorial arrangement. The obtained results were subjected to proper ANOVA and the statistical test Scott-Knott (SK) was used to compare mean values of the treatments at $P<0.05$. The test proposed by Scott Knott is a procedure of means grouping, considered an effective option to perform multiple comparisons without ambiguity in controlled conditions (Bhering et al., 2008). Data was processed in statistical software Infostat (Di Rienzo et al., 2011).

\section{Results}

Main effects of microorganisms applied on potato plants in greenhouse

For the experiment, higher significant tuber weight per plant (TWP) was obtained for the inoculation with the consortia of microorganisms Glomus intraradices + Bacillus subtilis compared to the inoculation with Glomus intraradices alone. Both treatments produced also significant higher values than the uninoculated control (table 3). There were significant differences for number of tubers per plant (TNP), tuber diameter (TDI) and mean tuber weight (MTW) for Glomus + Bacillus or Glomus inoculation. Control treatment obtained the highest fresh foliage weight (FFW) with respect to the rest of treatments. NPK treatment had a longer senescence period of foliage (DFS) compared to inoculation or control; the inoculation with Glomus + Bacillus consortia showed the shorter senescence period of foliage.

For agronomic traits (table 4), the inoculation with Glomus intraradices and Bacillus subtilis or Glomus intraradices alone, obtained the highest plant height at 30 days; it is necessary to state that plants were measured for plant height at the planting time, with no statistical differences. Vegetative uniformity (VUN) and plant vigor (VIG) were similar for inoculation treatments or control, as well as for stem diameter (SDI), number of leaflets per plant (NLP), number of inflorescences per plant (NFP) and number of sprouts per plant (NSP).

\section{Interactions between potato genotypes and inoculation treatments}

From evaluation of the factorial effects of potato genotypes and inoculation treatments in the greenhouse, there were some significant 
Table 3

Glomus intraradices and Bacillus subtilis effects on yield components, obtained from in vitro plantlets of five potato genotypes in greenhouse

\begin{tabular}{|c|c|c|c|c|c|c|c|}
\hline Inoculation $^{1}$ & TWP & TNP & TDI & MTW & DWF & FFW & DFS \\
\hline Control & $4.14^{c}$ & $1.82^{\mathrm{b}}$ & $0.96^{\mathrm{b}}$ & $1.73^{\mathrm{b}}$ & $37.31^{\mathrm{a}}$ & $111.73^{\mathrm{a}}$ & $6.90^{\mathrm{b}}$ \\
\hline Glomus & $5.93^{b}$ & $2.58^{\mathrm{a}}$ & $1.06^{\mathrm{b}}$ & $1.93^{\mathrm{b}}$ & $33.84^{\mathrm{a}}$ & $94.95^{\mathrm{b}}$ & $6.20^{\mathrm{b}}$ \\
\hline Glomus + Bacillus & $7.49^{\mathrm{a}}$ & $2.86^{\mathrm{a}}$ & $1.27^{\mathrm{a}}$ & $2.56^{\mathrm{a}}$ & $32.63^{\mathrm{a}}$ & $87.8^{\mathrm{b}}$ & $4.63 c$ \\
\hline NPK & $3.66^{\mathrm{c}}$ & $2.23^{\mathrm{b}}$ & $0.86^{\mathrm{b}}$ & $1.28^{\mathrm{b}}$ & $25.24^{\mathrm{b}}$ & $75.32^{\mathrm{b}}$ & $7.80^{\mathrm{a}}$ \\
\hline
\end{tabular}

${ }^{1}$ Average effect on five potato genotypes.

a,b,c Means with the same letter are not statistically different $(P<0.05)$.

Table 4

Glomus intraradices and Bacillus subtilis effects on agronomical traits of five potato genotypes obtained from in vitro plantlets in greenhouse

\begin{tabular}{lccccccc}
\hline Inoculation $^{1}$ & MPH & VUN & VIG & NFP & NLP & NSP & SDI \\
\hline Control & $19.50^{\mathrm{b}}$ & $2.00^{\mathrm{b}}$ & $4.30^{\mathrm{b}}$ & $2.80^{\mathrm{a}}$ & $21.85^{\mathrm{a}}$ & $6.60^{\mathrm{a}}$ & $0.56^{\mathrm{a}}$ \\
Glomus & $23.04^{\mathrm{a}}$ & $1.42^{\mathrm{b}}$ & $4.40^{\mathrm{b}}$ & $1.93^{\mathrm{a}}$ & $21.15^{\mathrm{a}}$ & $7.32^{\mathrm{a}}$ & $0.59^{\mathrm{a}}$ \\
Glomus + Bacillus & $25.60^{\mathrm{a}}$ & $1.50^{\mathrm{b}}$ & $4.17^{\mathrm{b}}$ & $2.25^{\mathrm{a}}$ & $21.95^{\mathrm{a}}$ & $7.82^{\mathrm{a}}$ & $0.56^{\mathrm{a}}$ \\
NPK & $15.07^{\mathrm{b}}$ & $3.95^{\mathrm{a}}$ & $6.05^{\mathrm{a}}$ & $1.30^{\mathrm{a}}$ & 11,18 & $3.42^{\mathrm{b}}$ & $0.45^{\mathrm{b}}$ \\
\hline
\end{tabular}

${ }^{1}$ Average effect on five potato genotypes.

a,b Means with the same letter are not statistically different according to SK test $(P<0.05)$.

interactions for tuber weight per plant (TWP), dry weight of foliage (DWF) and number of tubers per plant (NTP). Such differences can be explained as a result of crossed effects of the inoculation with Glomus intraradices and Bacillus subtilis or Glomus intraradices alone with potato cultivars or advanced clones in controlled conditions.

In potato genotypes, there was a clear effect of Glomus + Bacillus inoculation for tuber weight per plant, being more pronounced in Faustina and Unica (figure 1). For the dry weight of foliage, control plants had the best response in the potato genotypes evaluated, except for Faustina (figure 2). Similar trend as in tuber weight were showed for the number of tubers per plant, and Canchan had the lesser effect for inoculation treatments respect to control (figure 3 ).

\section{Discussion}

In the present research, the data indicated an increase in the tuber yield and quality as a 44 result of the use of microbial inoculants, as other evidence from the literature suggests (Calvo et al., 2010; Douds et al., 2007; Duffy \& Cassells, 2000). The existing microbial diversity associated with potato plants is very broad, and the maintenance of natural microbial population in the form of inoculants can help to reduce the effects derived from monoculture, strengthening the potato production system (Sessitsch \& Mitter, 2015). Moreover, soil microbial communities can help to the restoration of degraded soils, mainly regarding the fertility, the capacity for nutrient retention and the availability of elements necessary for the growing of potatoes (Turnbull et al., 2014). Agro ecological management consisting on the partial substitution of the conventional chemical inputs by microorganisms based products (PGPRs and mycorrhiza) can lead to an improvement of the environmental performance of the crop, which will be of interest in potato production (Main \& Franco, 2016).

Peruvian Agricultural Research 1(2), 40-47, 2019 
Microbial inoculants for potato production in greenhouse

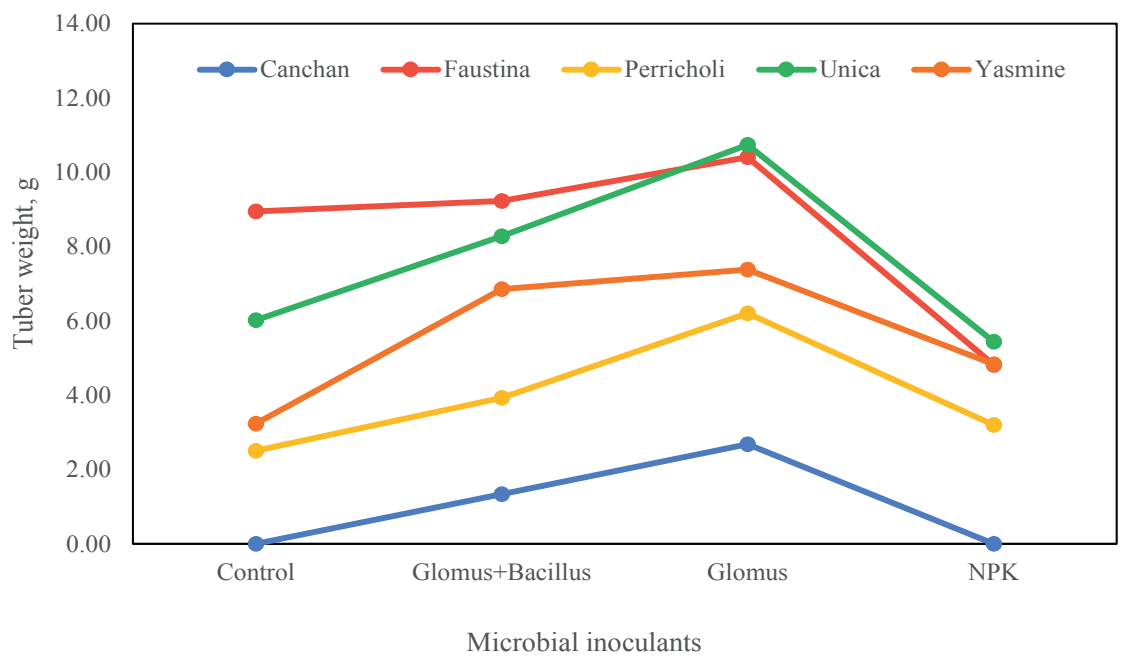

Figure 1. Effect of microbial inoculants on the tuber weight $(\mathrm{g})$ in five potato genotypes.

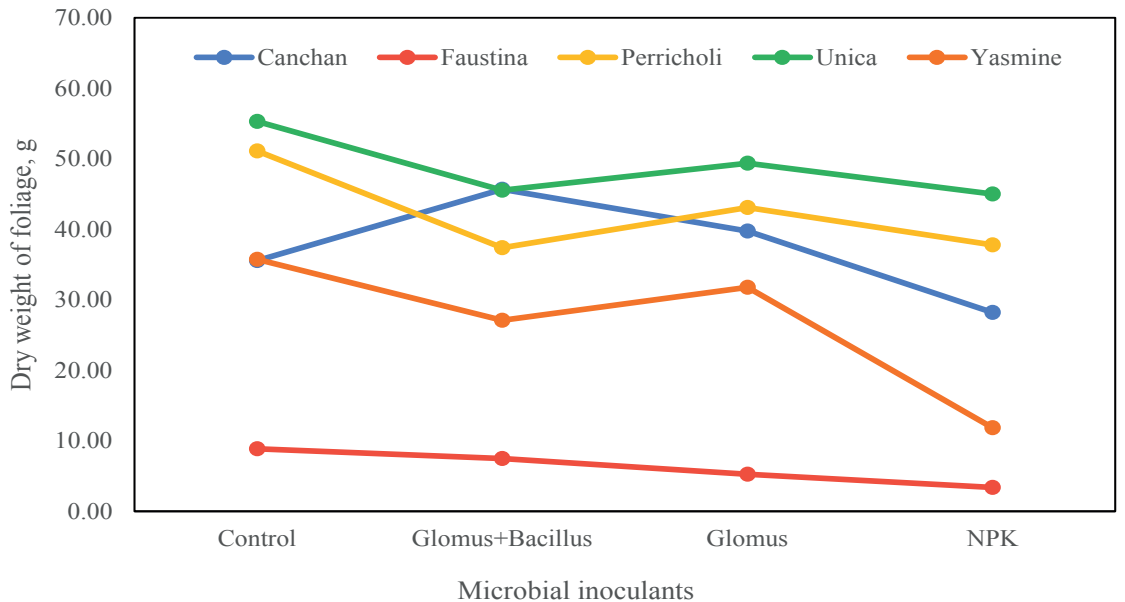

Figure 2. Effect of microbial inoculants on dry weight of foliage (g) in five potato genotypes.

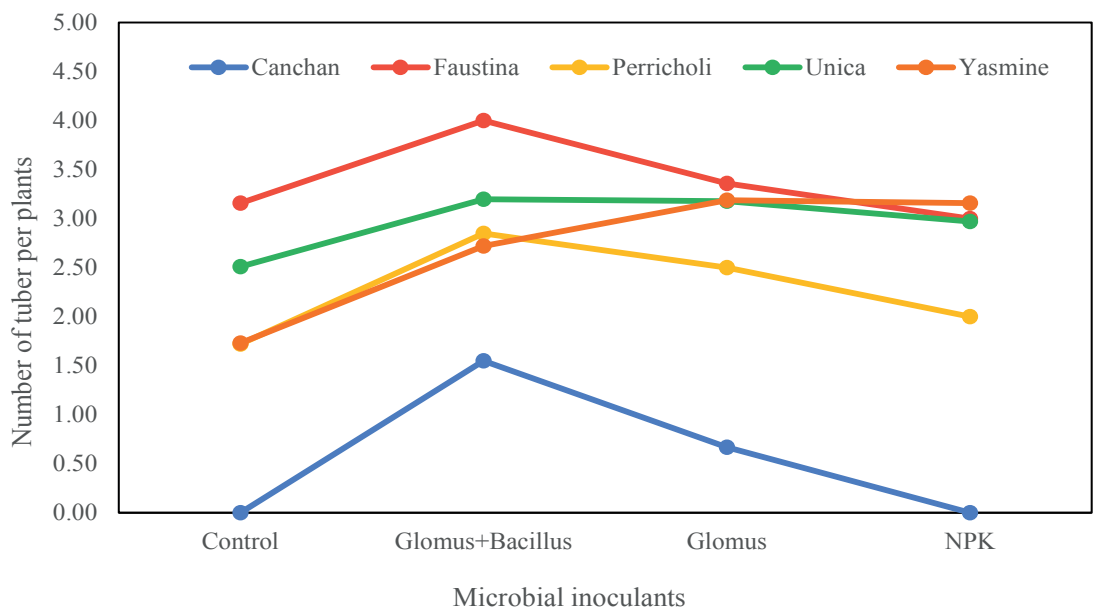

Figure 3. Effect of microbial inoculants on number of tubers per plant in five potato genotypes. 
By this moment, there are sufficient scientific evidences that through the symbiosis between plants and microorganisms, it is possible to reduce the use of high energy consumption inputs with negative environmental impact, such as fertilizers and agrochemicals, mitigating their harmful effects on the ecosystem (Brussard et al., 2007). The processes derived from the interaction between plants and microorganisms include the biological fixation of atmospheric nitrogen, solubilization and absorption of phosphorus, induced systemic resistance and plant immunity, among other physiological aspects, and it was demonstrated in this research as by Hijri (2016), showing the benefits of mycorrhizal-based inoculation on crop yield, using potato as a case study.

The results of this research are similar to Main \& Franco (2016), as they used B. subtilis and mycorrhizae to obtain increases in potato production in field conditions. However, as happens with another species, the generalization of the use of microbial products is often hampered by lack of efficacy and reliability (Van Loon, 2007), which makes the diffusion of this innovation difficult, and as considered by Devi et al. (2016), application of Bacillus in potato cultivation is not well established, in spite of its benefits.

\section{Conclusions}

The use of inoculants is an alternative for agronomic management of potato in greenhouse, because after inoculating the potato tuber propagules with selected elite bacterial strains or mycorrhizal fungi, several significant differences were observed compared to the uninoculated control, regarding increasing of the tubers yield and other important agronomic traits in the greenhouse. These results demonstrate that the use of microorganisms as $G$. intraradices and $B$. subtilis promote growth in potatoes, can improve tuber seed production, thereby being a strategy to increase the level of efficiency in potato, for quality seed production.

\section{Acknowledgements}

Universidad Nacional José Faustino Sánchez Carrión (Huacho) funded the project as a part 46 of the program of Socioeconomic Development Fund of Camisea - FOCAM; Laboratorio de Análisis de Suelos (UNALM) provided soil characterization analysis and help to design the experiment. CIP-Germplasm at Lima provided in vitro potato plants for the experiment. We want to thank Sady García-Bendezú and Doris Zúñiga-Dávila for the technical support and Dr. Rodomiro Ortiz (SLU) for the critical reading of this manuscript.

\section{References}

Aloo, B.N., Mbega, E.R. \& Makumba, B.A. (2019). Rhizobacteria-Based Technology for Sustainable Cropping of Potato (Solanum tuberosum L.). Potato Research, 62, 1-21. doi.org/10.1007/s11540-019-09432-1

Arcos, J., \& Zúñiga, D. (2015) Efecto de rizobacterias en el control de Rhizoctonia solani en el cultivo de papa. Ecología Aplicada, 14(2), 95-101.

Bhering, L.L., Cruz, C.D., Vasconcelos, E.D., Ferreira, A., \& Resende Junior, M.D. (2008). Alternative methodology for ScottKnott test. Crop Breeding and Applied Biotechnology, 8, 9-16.

Brussaard, L., De Ruiter, P.C., Brown, G.G. (2007) Soil biodiversity for agricultural sustainability. Agriculture, ecosystems \& environment, 121(3), 233-244. doi. org/10.1016/j.agee.2006.12.013

Calvo, P., Ormeño-Orrillo, E., Martínez-Romero, E., \& Zúñiga, D. (2010). Characterization of Bacillus isolates of potato rhizosphere from andean soils of Peru and their potential PGPR characteristics. Brazilian Journal of Microbiology, 41, 899-906. doi. org/10.1590/S1517-83822010000400008

Castillo, C., Huenchuleo, M.J., Michaud, A., \& Solano, J. (2016) Micorrización en un cultivo de papa adicionado del biofertilizante Twin-N establecido en un Andisol de la Región de La Araucanía. Idesia (Arica), 34(1), 39-45. doi.org/10.4067/S071834292016000100005

Davies, F.T., Calderón, C.M., Huaman, Z., \& Gómez, R. (2005) Influence of a flavonoid (formononetin) on mycorrhizal activity and potato crop productivity in the highlands of Peru. Scientia Horticulturae, 106(3), 318Peruvian Agricultural Research 1(2), 40-47, 2019 
329. doi.org/10.1016/j.scienta.2005.04.013

Devi, A.R., Kotoky, R., Pandey, P., \& Sharma,

G.D. (2016) Application of Bacillus spp. for Sustainable Cultivation of Potato (Solanum tuberosum L.) and the Benefits. In M. Islam, Rahman, P. Pandey , C. Jha, A. Aeron (Eds.), Bacilli and Agrobiotechnology (pp. 185-211). Cham,Switzerland: Springer. doi. org/10.1007/978-3-319-44409-39

Diallo, S., Crépin, A., Barbey, C., Orange, N., Burini, J.F., \& Latour, X. (2011) Mechanisms and recent advances in biological control mediated through the potato rhizosphere. FEMS Microbiology Ecology, 75, 351-364. doi.org/10.1111/j.1574-6941.2010.01023.x

Di Rienzo, J. A., Casanoves, F., Balzarini, M. G., Gonzalez, L., Tablada, M., \& Robledo, C. W. (2011). InfoStat. Software Estadístico. Universidad Nacional de Córdoba, Argentina. Disponible en: http://www. infostat.com.ar

Douds, D.D., Nagahashi, G., Reider, C., \& Hepperly, P.R. (2007) Inoculation with arbuscular mycorrhizal fungi increases the yield of potatoes in a high $\mathrm{P}$ soil. Biological agriculture \& horticulture, 25(1), 67-78. doi.org/10.1080/01448765.2007.10823209

Duffy, E.M., \& Cassells, A.C. (2000) The effect of inoculation of potato (Solanum tuberosum L.) microplants with arbuscular mycorrhizal fungi on tuber yield and tuber size distribution. Applied Soil Ecology, 15(2), 137-144. doi.org/10.1016/S09291393(00)00089-5

Hijri, M. (2016). Analysis of a large dataset of mycorrhiza inoculation field trials on potato shows highly significant increases in yield. Mycorrhiza, 26(3), 209-214. doi. org/10.1007/s00572-015-0661-4

Kennedy, A.C., \& Smith, K.L. (1995) Soil microbial diversity and the sustainability of agricultural soils. In H.P. Collins, G. P. Robertson \& M. J. Klug (Eds), The significance and regulation of soil biodiversity (pp. 75-86). Dordrecht, Netherlands: Springer. doi.org/10.1007/ BF02183056

Main, G., \& Franco, J. (2016). Efecto de la bacteria Bacillus subtilis y el hongo micorrízico arbuscular Glomus fasciculatum en la fertilización fosfórica en el cultivo de la papa (Solanum tuberosum ssp. andigena). Revista Latinoamericana de la Papa, 16(2), 250-269.

Ministerio de Agricultura y Riego (2015). Intenciones de siembra 2015-2016. Recuperado de: http://siea.minagri.gob. $\mathrm{pe} / \mathrm{siea} / \mathrm{sites} / \mathrm{default} /$ files/Resumen $\% 20$ Ejecutivo\%20Intenciones 4.pdf

Naqqash, T., Hameed, S., Imran, A., Hanif, M.K., Majeed, A., \& van Elsas, J.D. (2016) Differential Response of Potato toward Inoculation with Taxonomically Diverse Plant Growth Promoting Rhizobacteria. Frontiers in Plant Science, 7, 144. doi. org/10.3389/fpls.2016.00144

Oswald, A., Calvo, P., Zúñiga, D., \& Arcos, J. (2010) Evaluating soil rhizobacteria for their ability to enhance plant growth and tuber yield in potato. Annals Applied Biology, 157, 259-271. doi.org/10.1111/ j.1744-7348.2010.00421.x

Sessitsch, A., \& Mitter, B. (2015) 21st century agriculture: integration of plant microbiomes for improved crop production and food security. Microbial biotechnology, 8(1), 3233. doi.org/10.1111/1751-7915.12180

Turnbull, A.L., Campbell, I., \& Lazarovits, G. (2014) Resistance of bacterial communities in the potato rhizosphere to disturbance and its application to agroecology. Soil Biology and Biochemistry, 79, 125-131. doi.org/10.1016/j.soilbio.2014.09.011

Van Loon, L.C. (2007) Plant responses to plant growth-promoting rhizobacteria. European Journal of Plant Pathology, 119, 243-254. doi.org/10.1007/978-1-4020-6776-1_2

Velivelli, S.L., Kromann, P., Lojan, P., Rojas, M., Franco, J., Suarez, J.P., \& Prestwich, B.D. (2015). Identification of mVOCs from Andean rhizobacteria and field evaluation of bacterial and mycorrhizal inoculants on growth of potato in its center of origin. Microbial ecology, 69 (3), 652-667. doi. org/10.1007/s00248-014-0514-2

Yang, G., Wagg, C., Veresoglou, S.D., Hempel, S., \& Rillig, M.C. (2018). How soil biota drive ecosystem stability. Trends in plant science, 23(12),1057-1067. doi. org/10.1016/j.tplants.2018.09.007 